\title{
Pengaruh Good Corporate Governance dan Ukuran Perusahaan Pada Kinerja Keuangan Perusahaan Perbankan
}

\author{
Ni Ketut Sri Wahyuni ${ }^{1}$ \\ Fakultas Ekonomi dan Bisnis \\ Universitas Udayana, Indonesia. \\ Email: wahyuni_ketutsri@yahoo.co.id
}

\author{
I Made Sukartha ${ }^{2}$ \\ Fakultas Ekonomi dan Bisnis \\ Universitas Udayana, Indonesia.
}

\begin{abstract}
ABSTRAK
Kinerja keuangan bank merupakan gambaran tingkat keberhasilan yang dicapai oleh bank dalam kegiatan operasionalnya.Tujuan penelitian ini untuk mengetahui buktiempiris pengaruh GCG dan ukuran perusahaan padakinerja keuangan perusahaan perbankan.Teknik penentuan sampel purposive sampling. Total sampel dalam penelitian ini adalah 10 sampeldengan 45 pengamatan selama 5 tahunTeknik analisis data adalah analisisregresi linier berganda.Hasil penelitian membuktikan GCG berpengaruh positif pada kinerja keuangan perusahaan perbankan. Ukuran perusahaan berpengaruh positif pada kinerjakeuangan perusahaan perbankan.Hasil penelitian ini diharapkan bermanfaat bagi perusahaan perbankan agar terus berupaya menerapkan seluruh komponen GCG dan memperoleh peringkat CGPI yang terpercaya sehingga menjadi acuan investor.
\end{abstract}

Kata Kunci: Good Corporate Governance; Ukuran Perusahaan Dan Kinerja Keuangan.

The Effect of Good Corporate Governance and Company Size on the Financial Performance of Banking Companies

\section{ABSTRACT}

Bank financial performance is an illustration of the level of success achieved by the bank in its operational activities. The purpose of this study is to find out the empirical evidence of the effect of GCG and company size on the financial performance of banking companies. The technique for determining purposive sampling. The total sample in this study was 10 samples with 45 observation for 5 years. The data analysis multiple linear regression analysis. The results of the study prove that good corporate governance GCG ernance has a positive effect on the financial performance of banking companies. The size of the company has a positive effect on the financial performance of banking companies. The results of this study are expected to be useful for banking companies to continue to strive to implement all components of GCG and obtain a reliable CGPI rating so that it becomes a reference for investors.

Keywords: Good Corporate Governance; Company Size and Financial Performance.

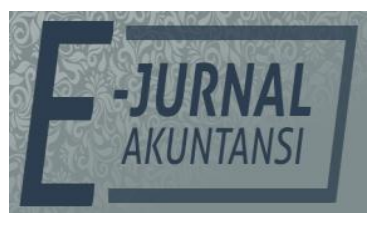

E-JA

e-Jurnal Akuntansi e-ISSN 2302-8556

Vol. 29 No. 1

Denpasar, Oktober

2019

Hal. 390-404

Artikel masuk:

11 Juli2019

Tanggal diterima: 16 Agustus 2019 


\section{PENDAHULUAN}

Laporan keuangan merupakan instrumen yang menyediakan informasi tentang posisi keuangan dan kinerja suatu perusahaan dalam periode waktu tertentu.Kinerja perusahaanmerupakan pengukur atas prestasi perusahaan yang timbul akibat prosespengambilan keputusan manajemen, karena memiliki hubungan efektivitaspemanfaatan modal, efisiensi dan rentabilitas dari kegiatan kinerja. Kinerjaperusahaan dapat dijadikan sebagai pedoman dalam mengukur keberhasilan suatuperusahaan. Kinerja keuangan yang dapat dicapai oleh perusahaan dalam satuperiode tertentu, merupakan gambaran sehat atau tidaknya suatu perusahaan (Fidhayatin dan Dewi, 2012).

Kinerja keuangan bank adalah suatu gambaran sampai mana tingkat keberhasilan yang dicapai oleh bank dalam kegiatan operasionalnya. Kinerja keuangan perbankan menjadi faktor utama untuk menilai keseluruhan kinerja perbankan itu sendiri. Mulai dari penilaian aset, utang, likuiditas dan lain sebagainya. Kinerja dalam perusahaan sangat penting karena kinerja merupakan suatu gambaran tentang prestasi suatu perusahaan yang dikelola oleh manajemen yang dapat dijadikan sebagai pedoman dalam mengukur keberhasilan perusahaan.Kinerja keuangan yang dapat dicapai oleh perusahaan dalam satuperiode tertentu, merupakan gambaran sehat atau tidaknya suatu perusahaan (Fidhayatin dan Dewi, 2012).

Perusahaan Perbankan menarik untuk diteliti pasca krisis ekonomi pada tahun 1997-1998 mengakibatkan perbankan di Indonesia mengalami keterpurukan, banyak bank dilikuidasi karena tidak mampu mempertahankan kinerjanya. Hal ini karena bank sukses dalam mengumpulkan dana masyarakat, namun penyaluran kredit kepada masyarakat mengalami penurunan. Akibatnya bank tidak cukup kredibel dari segi profitabilitas, hal ini tentunya berdampak pada kelangsungan modal perbankan. Pasca krisis 1997-1998 perekonomian di Indonesia masih naik turun, hingga pada tahun 2008 terjadilah krisis di negara adidaya Amerika Serikat yang berimbas pada perekonomian Indonesia. Krisis di tahun 2008 tidak separah tahun 1997 dan tidak berdampak terlalu besar pada sektor perbankan.Akan tetapi pada tahun 2011-2014 terjadi penurunan kinerja keuangan sektor perbankan yang dapat dilihat dari Return on Assets (ROA). Pada tahun 2011 ROA rata-rata sebesar 0,0172. Kemudian ROA rata-rata pada tahun 2012 mengalami kenaikan menjadi sebesar 0,0197. Namun, ROA rata-rata pada tahun 2013 dan 2014 mengalami penurunan terus menerus yaitu menjadi sebesar 0,0173 dan 0,0126 (Isti'adah, 2015).

Ada beberapa faktor yang dapat menyebabkan terjadinya kinerja keuangan, yakni good corporate governance (GCG) dan ukuran perusahaan. Lemahnya implementasi tata kelola perusahaan yang baik menjadi penyebab terjadinya ketidakstabilan ekonomi yang berdampak pada penurunan kinerja keuangan perusahaan. Good Corporate Governance adalah salah satu tata kelola Bank yang menerapkan prinsip -prinsip keterbukaan (transparancy), akuntabilitas (accountability), pertanggung jawaban (responsibility), idenpendensi (idependency), dan kewajaran (fairness). Dengan diterapkannya good corporate governance secara efektif dan efisien akan menciptakan kepercayaan publik terhadap perusahaan yang dapat mengurangi biaya pengawasan sehingga dapat menciptakan kinerja yang baik bagi perusahaan. 
Ukuran perusahaan merupakan nilai besar kecilnya perusahaan yang ditunjukan oleh total aset, total penjualan, jumlah laba, beban pajak sehingga memengaruhi kinerja sosial perusahaan karena perusahaan yang besar mempunyai pandangan yang lebih jauh, sehingga lebih berpartisipasi dalam menumbuhkan kinerja sosial perusahaan dan menyebabkan tercapainya tujuan perusahaan.

Terdapat beberapa rasioprofitabilitas yang dapat digunakan untuk mengukur kinerja perusahaan,diantaranya yaitu Return on Assets (ROA), Return on Equity (ROE), dan Net ProfitMargin (NPM). Dalam penelitian ini akan digunakan Return on Assets (ROA).ROA merupakan rasio untuk mengukur profitabilitas perbankan.ROA merupakan rasio untuk mengukur kemampuan manajemen bank dalam memperoleh laba. ROA mencerminkan seberapa besar laba yang bisa dicetak perusahaan dengan menggunakan seluruh asetnya. Semakin tinggi ROA menunjukkan semakin baik dalam penggunaan aset bank.

Kinerja perusahaan dipandang sebagai barometer keberhasilan perusahaan dalam menerapkan kebijakan yang telah diambilnya. Salah satu faktor yang memengaruhi kebijakan manajemenyang berimplikasi pada kinerjakeuangan, antara lain corporate governance(Fallatah dan Dickins, 2012). Suatu perusahaan dengan manajemen yang menerapkansistem pengelolaan yang baik akan memberikanperlindungan dan jaminan hak kepada para stakeholders (Prasinta, 2012). Corporate governance sebagai good corporate governance (GCG) merupakan struktur, sistem dan proses yang digunakan oleh pemangku kepentingan dalam rangka memberikan nilai tambah bagi perusahaan secara berkesinambungan untuk jangka waktu panjang. Tujuan utama penerapan GCG adalah untuk meningkatkan nilai tambah bagi stakeholder (Hapsari, 2010).Oleh karena itu, manajemen berkewajiban untuk memberikan informasi akurat tentangkondisi perusahaan yang sebenarnya.

Penelitian terdahulu Variabel good corporate governance (GCG) dan ukuran perusahaan masih terdapat hasil penelitian yang berbeda. Memdani et al. (2015) hasil penelitiannya menunjukkan bahwa good corporate governance berpengaruh positif pada kinerja perusahaan. Indarti dan Extaliyus (2013) hasil penelitiannya menunjukan bahwa CGPI berpengaruh positif pada kinerja keuangan. Putri (2006) menunjukkan bahwa penerapan GCG dapat memengaruhi kinerja perusahaan. Penelitian Fallatah dan Dickins, (2012) juga menunjukkan bahwa tidak ada pengaruh good corporate governance pada kinerja perusahaan. Siahaan (2008) menunjukkan bahwa terdapat hubungan yang tidak signifikan antara penerapan GCG pada kinerja keuangan perusahaan. Nuswandari (2009) menunjukan bahwa variabel corporate governance belum mampu memengaruhi kinerja perusahaan. Hasil penelitian Paradita (2009) juga menunjukkan bahwa variabel GCG tidak berpengaruh secara parsial pada kinerja keuangan.

Variabel ukuran perusahaan Lin (2006) serta Wright et al.(2009) menyatakan ukuran perusahaan berpengaruh positif pada kinerja. Jadi, semakin besar ukuran perusahaan,semakin bagus kinerja keuangannya. Namun, hasil yang berbeda ditunjukkan oleh penelitian Huang et al. (2002) dan Talebnia et al.(2010) menyatakan bahwa tidak terdapat pengaruhukuran perusahaan pada kinerja perusahaan.Uyun (2011) dalam penelitiannya menemukan bukti bahwa ukuran perusahaan berpengaruh positif pada kinerja keuangan perusahaan. 
Mahmood dan Abbas (2011) mengatakan bahwa ukuran perusahaan mempunyai hubungan positif pada kinerja keuangan perusahaan. Isbanah (2013) menyatakan bahwa ukuran perusahaan tidak berpengaruh pada kinerja perusahaan. Gill dan Obradovich (2017) mengatakan bahwa ukuran perusahaan mempunyai hubungan positif pada kinerja keuangan perusahaan. Epi (2017) menyatakan bahwa ukuran perusahaan tidak berpengaruh pada kinerja keuangan.Dengan demikian good corporate governance secara teoritis seharusnya memiliki pengaruh positif dan masih adanya perbedaan hasil penelitian terdahuluoleh karena demikian peneliti tertarik untuk meneliti kembali.

Teori keagenan ini dikembangkan oleh Jensen (1986). Teori keagenan merupakan sebuah teori yang berkaitan dengan hubungan principal dengan agent. Suatu hubungan agency muncul ketika satu atau lebih individu yang disebut prinsipal memperkerjakan satu atau lebih individu lain yang disebut agen, untuk melakukan layanan tertentu dan kemudian mendelegasikan otoritas pengambilan keputusan kepada agen.Teori keagenan digunakan untuk mengatasi dua permasalahan yang dapat terjadi dalam hubungan keagenan (Darmawati dkk., 2005). Pertama adalah masalah keagenan yang timbul pada saat (a) keinginan atau tujuan dari prinsipal dan agen berlawanan dan (b) merupakan suatu hal yang sulit atau mahal bagi prinsipal untuk melakukan verifikasi tentang apa yang telah benar-benar dilakukan oleh agen.

Menurut Scott (2000) menyatakan bahwa inti dari teori keagenan adalah pendesainan kontrak yang tepat untuk menyelaraskan kepentingan prinsipal dan agen dalam hal terjadi konflik kepentingan.Kontrak yang efisien adalah kontrak yang memenuhi dua faktor, yaitu 1) agen dan prinsipal memiliki informasi yang simetris, 2) risiko yang dipikul agen berkaitan dengan imbal jasanya adalah kecil (Sukartha, 2007).Alasan menggunakan Agency Teori karena melibatkan dua pihak yaitu investor dan pemilik perusahaan. Pemilik perusahaan akan berusaha menerapkan corporate governance sehingga mendapat kepercayaan dari investor sehingga dapat mempercayakan modalnya kepada perusahaan.

Teori keagenan menyatakan bahwa kepentingan yang terjadi antara pemilik perusahaan dengan manajemen dapat diminimalkan dengan suatu mekanisme monitoring yang mampu menyeimbangkan kepentingan antara pihak manajemen dan pemegang saham maupun pihak lainnya. Oleh sebab itu, emiten diharapkan dapat mempertimbangkan penerapan good corporate governance. Corporate governance sangat berkaitan dengan bagaimana membuat parainvestor yakin bahwa manajer akan memberikan keuntungan bagi mereka, yakin bahwa manajer tidak akan menggelapkan atau tidak mengalihkan ke dalam proyek-proyek yang tidak menguntungkan berkaitan dengan modal yang telah ditanamkan oleh investor (Prasinta, 2012). Oleh sebab itu, manajemen diharapkan dapat mempertimbangkan penerapan good corporate governance, kerena perusahaan yang menerapkan good corporate governance secara efektif dan efisien akan menciptakan kepercayaan publik atau emiten pada perusahaan, sehingga dengan kepercayaan yang ada dapat mengurangi biaya pengawasan (monitoring cost), dengan demikian rendahnya biaya pengawasan dapat menciptakan kinerja yang baik bagi perusahaan perbankan. Berdasarkan uraian 
teori keagenan bahwa semakin baik penerapan good corporate governance, maka kinerja perusahaan perbankan juga akan mengalami peningkatan.

Berdasarkan laporan Corporate Governance Perception Index(CGPI) 2004, pengelolaan badan usaha masih sangat lemah, salah satunya yang terjadi pada sektor perbankan.Pelaksanaan good corporate governance masih belum diterapkan secara konsisten dan maksimal pada badan usaha termasuk sektor perbankan.Padahal sektor perbankan merupakan faktor pendukung perekonomian di Indonesia.Oleh karenanya, regulasi yang sangat ketat sebagai bentuk pengendalian pada pengelolaan sektor perbankan telah diselenggarakan demi terciptanya iklim pengelolaan yang baik dan praktik bisnis yang sehat pada badan usaha. Sektor perbankan merupakan lembaga yang menghimpun dana masyarakat sehingga berbagai upaya penyelenggaraan regulasi telah diatur secara ketat. Salah satunya adalah peraturan mengenai pelaksanaan good corporate governance untuk bank umum yang telah diatur dalam Peraturan Bank Indonesia Nomor 8/14/PBI/ 2006 (Natalia dan Laksono, 2013).

Menurut Rachmawati (2013) menyatakan bahwa profitabilitas adalah alat ukur yang paling tepat untuk menilai kinerja suatu bank. Kemampuan bank untuk mendapatkan keuntungan akan berpatokan pada kinerja manajemen bank yang bersangkutan untuk mengelola total aset yang dimiliki oleh suatu perusahaan. Rasio profitabilitas merupakan salah satu ukuran dalam melihat kinerja keuangan perbankan, dalam penelitian ini rasio profitabilitas tersebut

proksikan dengan Return On Asset (ROA). Apabila nilai ROA tinggi maka profitabilitas perusahaan meningkat, sehingga dampaknya adalah peningkatan profitabilitas atau keuntungan yang dinikmati oleh pemegang saham (Almadany, 2012).

Menurut FCGI (2001: 1) mendefinisikan corporate governance sebagai suatu perangkat peraturan yang menetapkan hubungan antara pemegang saham, pengurus, pihak kreditur, pemerintah, karyawan serta pemegang kepentingan internal dan eksternal lainnya sehubungan dengan hak-hakdan kewajiban mereka. Semakin baiknya corporate governance perusahaan akan membuat kinerja perusahaan semakin baik. Memdani et al. (2015) menunjukkan bahwa good corporate governance berpengaruh positif pada kinerja perusahaan. Indarti dan Extaliyus (2013) hasil penelitiannya menunjukan bahwa CGPI berpengaruh positif pada kinerja keuangan. Putri (2006) menunjukkan bahwa penerapan GCG dapat memengaruhi kinerja perusahaan. Berdasarkan uraian tersebut dapat dijelaskan bahwa, semakin baik penerapan good corporate governance dalam suatu perusahaan, maka dapat meningkatkan kinerja keuangan. Berdasarkan alasan tersebut, hipotesis yang dapat dikembangkan adalah:

$\mathrm{H}_{1}$ : Good corporate governance berpengaruh positif pada kinerja keuangan perusahaan perbankan.

Teori keagenan merupakan sebuah teori yang berkaitan dengan hubungan principal dengan agent. Ketika hubungan kontraktual tersebut terjadi maka akan timbul biaya agensi (agency cost) (Anthony dan Govindarajan, 2007). Tujuan teori keagenan menciptakan kontrak yang efisien, Kontrak yang efisien adalah kontrak yang memenuhi dua faktor, yaitu 1) agen dan prinsipal memiliki informasi yang simetris, 2) risiko yang dipikul agen berkaitan dengan imbal 
jasanya adalah kecil (Sukartha, 2007). Semakin bagus tata kelola sebuah perusahaan maka seharusnya semua komponen didalam perusahaan bekerja sesuai dengan harapan atau sesuai dengan rencana, oleh karena itu biaya-biaya seperti pengawasan, boanding, residual loss akan menjadi semakin rendah ketika biaya semakin rendah maka keuntungan naik apabila keuntungan naik maka kinerja meningkat. Berdasarkan uraian teori keagenan bahwa semakin besar ukuran perusahaan maka semakin baik kinerja perusahaan.

Ukuran perusahaan dalam penelitian ini diukur dengan melihat seberapa besar asset yang dimiliki oleh sebuah perusahaan. Aset yang dimiliki perusahaan ini menggambarkan hak dan kewajiban serta permodalan perusahaan. Ukuran perusahaan akan berpengaruh pada perkembangan perusahaan. Hesti (2010) dan Uyun (2011) dalam penelitiannya menemukan bukti bahwa ukuran perusahaan berpengaruh positif pada kinerja keuangan perusahaan. Mahmood dan Abbas (2011) mengatakan bahwa ukuran perusahaan mempunyai hubungan positif pada kinerja keuangan perusahaan. Gill dan Obradovich (2017) mengatakan bahwa ukuran perusahaan mempunyai hubungan positif pada kinerja keuangan perusahaan. Perusahaan dengan aset besar biasanya akan mendapatkan perhatian lebih dari masyarakat. Hal ini akan menyebabkan perusahaan lebih berhati-hati dalam melakukan pelaporan keuangannya. Perusahaan diharapkan akan selalu berusaha menjaga stabilitas kinerja keuangan mereka. Berdasarkan uraian tersebut dapat dijelaskan bahwa semakin besar sebuah perusahaan maka semakin bagus kualitas kinerjanya. Berdasarkan alasan tersebut, hipotesis yang dapat dikembangkan adalah:

$\mathrm{H}_{2}$ : Ukuran perusahaan berpengaruh positif pada kinerja keuangan perusahaan perbankan.

\section{METODE PENELITIAN}

Penelitian ini dilakukan pada perusahaan perbankan yang terdaftar dalam penilaian CGPI tahun 2013-2017.Sektor ini sangat erat kaitannya dengan good corporategovernance karena adanya regulasi, selain tentang penyampaian laporan tahunan yang memuat laporan tata kelola perusahaan, sesuai Peraturan Bank Indonesia No.8/4/PBI/2006 yang disempurnakan dengan PBINo.8/14/2006 serta Surat Edaran Bank Indonesia No.9/12/DPNP perihal Pelaksanaan Good Corporate Governance Bagi Bank Umum, bank diwajibkan untuk menyajikan informasi kepada stakeholder tentang pelaksanaan good corporate governance dan kesimpulan umum hasil self assesment pelaksanaan good corporate governance, sehingga pengungkapan corporate governance menjadi sangat penting.

Obyek penelitian ini adalah kinerja keuangan pada seluruh perusahaan perbankan yang masuk dalam penilaian Corporate Governance Perception Index (CGPI) hasil survei The Indonesian Institute of Corporate Governance (IICG) dan majalah SWA. Tahun penelitian yang diambil mulai tahun 2013 - 2017. Variabel terikat dalam penelitian ini adalah kinerja keuangan. Variabel bebas yaitu good corporate governancedan ukuran perusahaan.

Populasi dalam penelitian ini adalah seluruh perusahaan perbankan.Teknik penentuan sampel yang digunakan dalam penelitian ini adalah metode purposive sampling dengan kriteria seluruh perusahaan perbankan dan pernah terdaftar dalam penilaian CGPI mulai tahun 2013-2017 yang dilakukan oleh IICG dan 
dipublikasikan oleh majalah SWA. Total sampel dalam penelitian ini adalah 10 sampel dengan 45 pengamatan selama 5 tahun.

Kinerja keuangan adalah alat untuk mengukur prestasi kerja keuangan perusahaan melalui struktur permodalannya(Munawir, 2010: 31). Penilaian kinerja keuangan perusahaan harus diketahui output maupun inputnya. Kinerja keuangan perusahaan dalam penelitian ini diukur dengan menggunakan Return on assets (ROA) yang menunjukkan kemampuan perusahaan dengan menggunakan seluruh aktiva yang dimiliki untuk menghasilkan laba setelah pajak. Dapat dirumuskan sebagai berikut:

ROA $=\frac{\text { Laba Bersih }}{\text { Total Aset }}$

Good Corporate Governance dalam penelitian ini diukur menggunakan score Corporate Gonvernance Perception Index (CGPI) perusahaan dalam penilaian The Indonesian Most Trusted Companies CGPI yang dipublikasikan oleh majalah SWA, alasan digunakan Corporate Gonvernance Perception Index dikarenakan laporan yang dilakukan oleh IICG dapat memberikan gambaran secara langsung mengenai penerapan GCG di dalam perusahaan. Rating level pada CGPI yaitu: sangat terpercaya $(85,00-100)$, terpercaya $(70,00-84,99)$ dan, cukup terpercaya $(55,00-69,99)$

Menurut Sari (2014: 22-23), ukuran perusahaan adalah suatu cara yang dapat mengklasifikasi perusahaan dengan berbagai cara yaitu total aset, jumlah penjualan, jumlah tenaga kerja, dan lain-lain. Semakin besar total aset maupun penjualan, maka akan semakin besar pula ukuran sebuah perusahaan. Ukuran perusahaan dapat diukur dengan berbagai macam cara seperti total aset, jumlah penjualan, dan jumlah tenaga kerja. Dalam penelitian ini, ukuran perusahaan diukur dengan logaritma dari total asset (Log total asset) yang dimiliki perusahaan. Hal ini disebabkan karena besarnya total aset masing-masing perusahaan berbeda bahkan mempunyai selisih yang besar, sehingga dapat menyebabkan nilai yang ekstrim. Rumus yang digunakan untuk mengukur ukuran perusahaan yaitu:

Ukuran Perusahaan $\left(X_{2)}=\log\right.$ Total Asset

Metode pengumpulan data yang digunakan adalah metode observasi non partisipan yaitu teknik pengumpulan data di mana peneliti tidak terlibat secara langsung dan hanya sebagai pengamat independen. Data yang dipergunakan dalam penelitian ini adalah data CGPI yang dipublikasikan oleh IICG (www.iicg.org) dan data laporan keuangan tahunan perusahaan perbankan yang mempublikasikan laporan keuangan.Jenis data yang digunakan dalam penelitian ini adalah, Data kuantitatif yang digunakan dalam penelitian ini adalah hasil pemeringkatan CGPI tahun 2013-2017 dan laporan keuangan tahunan perusahaan perbankan yang terdaftar dalam penilaian CGPI.Data kualitatif yang digunakan dalam penelitian ini adalah daftar perusahaan perbankan yang mempublikasikan laporan keuangan tahun 2013-2017.Sumber data yang digunakan dalam penelitian ini adalah data sekunder.Data sekunder dalam penelitian ini adalahhasil pemeringkatan CGPI tahun 2013-2017 yang diperoleh melalui websiteIICG dan laporan keuangan tahunan perusahaan perbankan yang terdaftar dalam penilaian CGPI. 
Teknik analisis data yang digunakan dalam penelitian ini adalah analisis regresi linier berganda. Teknik ini digunakan karena pada penelitian ini menggunakan lebih dari satu variabel bebas dengan satu variabel terikat. Salah satu syarat sebelum melakukan analisis regresi linier berganda adalah model dalam penelitian harus lolos uji asumsi klasik. Apabila model dalam penelitian yang dibuat sudah dinyatakan valid dan sudah memenuhi asumsi-asumsi dasar dalam analisis regresi maka, uji dapat dilanjutkan dengan menggunakan uji analisis regresi linier berganda.Model persamaan regresi yang digunakan dalam penelitian ini diuji dengan tingkat signifikansi $a=5 \%$. Model regresi linear berganda dirumuskan sebagai berikut.

$Y=\beta_{0}+\beta_{1} X_{1}+\beta_{2} X_{2}+e$

Keterangan:

$\mathrm{Y}=$ Kinerja keuangan

$\beta_{0}=$ Konstanta

$\beta_{\mathrm{i}}=$ Koefisien Regresi, $\mathrm{i}=1,2$

$\mathrm{X}_{1}=$ Good corporate governance

$\mathrm{X}_{2}=$ Ukuran perusahaan

$\mathrm{e}=$ standar error

\section{HASIL DAN PEMBAHASAN}

Statistik deskriptif dalam penelitian memberikan gambaran atau deskripsi suatu data yang dilihat dari nilai rata-rata (mean), standar deviasi, nilai maksimum dan nilai minimum. Hasil statistik deskriptif disajikan pada Tabel 1.

Tabel 1. Hasil Uji Statistik Deskriptif

\begin{tabular}{lrrrrr}
\hline & N & Minimum & Maximum & \multicolumn{1}{c}{ Mean } & Std. Deviation \\
\hline GCG & 45 & 73.50 & 93.86 & 86.0318 & 4.05130 \\
Ukuran Perusahaan & 45 & 6.04 & 9.05 & 8.1462 & .75345 \\
ROA & 45 & .00 & .03 & .0172 & .00891 \\
\hline
\end{tabular}

Sumber : Data Penelitian, 2019

Statistik deskriptif dalam penelitian ini disajikan untuk memberikan informasi tentang karakteristik variabel penelitian. Berdasarkan hasil uji statistik deskriptif pada Tabel 1 nilai rata-rata Good Corporate Governance pada perusahan perbankan pada periode penelitian sebesar 86,0318 termasuk dalam kategori terpercaya. Nilai minimum adalah 73,50 terdapat pada PT. Bank Mandiri Taspen Pos pada tahun 2013. Sedangkan nilai maksimum sebesar 93,86 dimiliki oleh PT. Bank Mandiri (Persero) Tbk dengan kategori sangat terpercaya.

Rata-rata ukuran perusahaan yang dibentuk berdasarkan nilai log total asset sebesar 8,1462 dengan nilai maksimum sebesar 9,05 dan nilai minimum sebesar 6,24. Besarnya nilai standar deviasi yaitu 0,75345 lebih rendah dari nilai rata-rata membuktikan bahwa tidak terjadi fluktuasi pada data total aset selama periode pengamatan pada perusahaan perbankan.

Nilai rata-rata ROA sebesar 0,0172 dengan nilai maksimum sebesar 0,03 dan nilai minimum sebesar 0,00. Nilai standar deviasi sebesar 0,00891 lebih rendah dari nilai rata-rata, menunjukkan bahwa data ROA tidak berfluktuasi selama periode pengamatan. 
Tabel 2. Hasil Uji Normalitas

\begin{tabular}{lc}
\hline & Unstandardized Residual \\
\hline$N$ & 45 \\
Test Statistic & 0.088 \\
Asymp.Sig (2-tailed) & 0.200 \\
\hline
\end{tabular}

Sumber : Data Penelitian, 2019

Berdasarkan Tabel 2 menunjukkan bahwa nilai Test Statistic sebesar 0,088 dengan nilai Asymp Sig (2-tailed) sebesar 0,200 > 0,05 menunjukkan bahwa data yang digunakan dalam persamaan regeresi merupakan data yang berdistribusi normal.

Tabel 3. Hasil uji Autokorelasi

\begin{tabular}{cccc}
\hline Nilai DW & Nilai dL & Nilai dU & 4 -dU \\
\hline 1,966 & 1,4625 & 1,6283 & 2,3717 \\
\hline
\end{tabular}

Sumber : Data Penelitian, 2019

Berdasarkan Tabel 3 menunjukkan bahwa nilai Durbin Watson sebesar 1,966 dan nilai tersebut lebih besar dari nilai dU dan lebih kecil dari 4-dU. Dapat dijelaskan bahwa data yang digunakan dalam penelitian ini merupakan data yang tidak mengalami gejala autokorelasi.

Tabel 4. Hasil Uji Heteroskedastisitas

\begin{tabular}{|c|c|c|}
\hline Variabel & $t$ & Sig \\
\hline GCG & $-1,30600$ & 0,199 \\
\hline Ukuran Perusahaan & 0,777 & 0,442 \\
\hline
\end{tabular}

Sumber : Data Penelitian, 2019

Berdasarkan hasil uji heteroskedastisitas menunjukkan bahwa nilai signifikan terhadap variabel terikatnya yaitu Absolut Residual (Abres). Ini

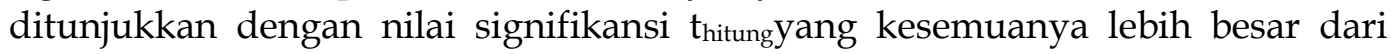
alpha $(\alpha=0,05)$. Jadi dapat disimpulkan bahwa pada model regresi tidak ditemukan gejala heteroskedastisitas.

Tabel 5. Hasil Uji Multikolinearitas.

\begin{tabular}{lcc}
\multicolumn{1}{c}{ Variabel } & Tolerance & VIF \\
\hline GCG & 0,614 & 1,628 \\
Ukuran Perusahaan & 0,614 & 1,628 \\
\hline
\end{tabular}

Sumber : Data Penelitian, 2019

Berdasarkan hasil Uji Multikolinearitas, dapat diketahui bahwa tidak ada variabel independen yang memiliki nilai Tolerance tidak kurang dari 0.10 dan nilai VIF tidak lebih dari 10. Analisis ini menunjukkan bahwa tidak terdapat gejala multikolinearitas terhadap variabel penelitian, sehingga layak untuk digunakan dalam pengujian selanjutnya.

Salah satu syarat sebelum melakukan analisis regresi linier berganda adalah model dalam penelitian harus lolos uji asumsi klasik. Model dalam penelitian yang dibuat sudah dinyatakan valid dan sudah memenuhi asumsiasumsi dasar dalam analisis regresi maka, uji dapat dilanjutkan dengan menggunakan uji analisis regresi linier berganda. 
Tabel 6. Hasil Analisis Regresi Linier Berganda

\begin{tabular}{|c|c|c|c|c|c|}
\hline \multirow{2}{*}{ Variabel } & \multicolumn{2}{|c|}{$\begin{array}{c}\text { Unstandardized } \\
\text { Coefficients }\end{array}$} & \multirow{2}{*}{$\begin{array}{c}\text { Standar } \\
\text { Coefficients } \\
\text { Beta }\end{array}$} & \multirow[t]{2}{*}{$\mathrm{t}$} & \multirow{2}{*}{ Sig. } \\
\hline & $B$ & Std. Error & & & \\
\hline (Constant) & $-0,098$ & 0,020 & & $-4,839$ & 0,000 \\
\hline GCG & 0,001 & 0,000 & 0,407 & 3,005 & 0,004 \\
\hline Ukuran Perusahaan & 0,005 & 0,002 & 0,399 & 2,947 & 0,005 \\
\hline $\mathrm{F}$ & \multicolumn{2}{|c|}{23,370} & & & \\
\hline $\operatorname{Sig} F$ & \multicolumn{2}{|c|}{0,000} & & & \\
\hline R Square & \multicolumn{2}{|c|}{0,527} & & & \\
\hline Adjusted RSquare & \multicolumn{2}{|c|}{0,504} & & & \\
\hline
\end{tabular}

Sumber : Data Penelitian, 2019

Berdasarkan Tabel 6. dapat dibuat secara sistematis persamaan regresinya adalah sebagai berikut :

$$
Y=-0,098+0,001 X_{1}+0,005 X_{2}
$$

Berdasarkan model persamaan regresi menyebutkan bahwa nilai konstanta sebesar-0,098, artinya apabila variabel Good Corporate Governance dan ukuran perusahaan tidak mengalami perubahan, maka kinerja perusahaan perbankan adalah negatif sebesar -0,098. Nilai koefisien regresi variabel GCG sebesar 0,001 artinya peningkatan pada variabel GCG akan diikuti oleh peningkatan kinerja keuangan pada perusahaan perbankan dengan asumsi variabel lain konstan. Nilai koefisien regresi variabel ukuran perusahaan sebesar 0,005 artinya peningkatan pada variabel ukuran perusahaanakan diikuti oleh peningkatan pada kinerja keuangan perusahan perbankan.

Berdasarkan Tabel 6 dapat diketahui bahwa besarnya nilai Adjusted $\mathrm{R}$ square sebesar 0,504 yang berarti 50,4 persen variabel kinerja keuangan dijelaskan oleh variabel GCG dan ukuran perusahaan. Sedangkan sisanya sebesar 49,6 persen dijelaskan oleh variabel lain yang tidak dimasukkan dalam model penelitian.

Uji F menghasilkan $F_{\text {hitung }}$ sebesar 23,370 dengan signifikansi sebesar 0,000 lebih kecil dari $\alpha=0,05$ ( $\alpha=5$ persen), yang berarti bahwa model yang digunakan dalam penelitian ini telah layak (fit). Dengan demikian model penelitian yang digunakan layak dan pembuktian hipotesis dapat dilanjutkan.

Tujuan teori keagenan menciptakan kontrak yang efesien, kontrak yang efesien adalah kontrak dengan biaya keagenan yang rendah, apabila Good Corporate Governance berpengaruh positif itu berarti bahwa ternyata penerapan Good Corporate Governancesecara efektif dan efesien di dalam perusahaan perbankan yang diteliti akan menciptakan kepercayaan publik atau emiten pada perusahaan, sehingga dengan kepercayaan yang ada dapat mengurangi biaya pengawasan, dengan demikian rendahnya biaya pengawasan dapat menciptakan kinerja yang baik bagi perusahaan perbankan.

Berdasarkan hasil pengujian hipotesis disimpulkan bahwa ukuran perusahaan berpengaruh positif pada kinerja keuangan perusahaan perbankan. Teori keagenan merupakan sebuah teori yang berkaitan dengan hubungan principal dengan agent. Ketika hubungan kontraktual tersebut terjadi maka akan timbul biaya agensi (agency cost) (Anthony dan Govindarajan, 2007). 
Apabila ukuran perusahaan berpengaruh positif itu berarti bahwa ternyata ukuran perusahaan dilihat dari besar atau kecilnya sebuah perusahaan, karena semua komponen pengawasan, pengendalian intern dan tata kelola di dalam perusahaan besar lebih bagus dibandingkan perusahaan kecil sehingga kinerja pada perusahaan besar semakin efektif dan efisien maka biaya semakin rendah, rendahnya biaya pengawasan dapat menciptakan kinerja yang baik bagi perusahaan perbankan sehingga mengakibatkan pengaruhnya menjadi positif.

Hasil Pengujian hipotesis menujukkan bahwa Good Corporate Governance berpengaruh positif pada kinerja keuangan perusahaan perbankan. Hal ini ditunjukkan dengan nilai signifikan sebesar 0,004 yang nilainnya lebih kecil dari tingkat signifikan yang ditetapkan $(\alpha=0,05)$ dan memiliki koefisien sebesar 0,001 . Sehingga hipotesis pertama $\left(\mathrm{H}_{1}\right)$ diterima yakni Good Corporate Governance terbukti berpengaruh positif pada kinerja keuangan. Hasil pengujian hipotesis tersebut mendukung hipotesis bahwa semakin tinggi penerapan Good Corporate Governance maka semakin tinggi kinerja keuangan perusahaan perbankan. Hasil penelitian ini juga memperkuat hasil penelitian yang dilakukan oleh Indarti dan Extaliyus (2013) hasil penelitiannya menunjukan bahwa CGPI berpengaruh positif pada kinerja keuangan. Memdani et al.(2015) menunjukkan bahwa good corporate governance berpengaruh positif pada kinerja perusahaan. Putri (2006) menunjukkan bahwapenerapan GCG dapat memengaruhi kinerja perusahaan. Berdasarkan uraian tersebut dapat dijelaskan bahwa, semakin baik penerapan good corporate governance dalam suatu perusahaan, maka dapat meningkatkan kinerja keuangan.

Teori keagenan merupakan sebuah teori yang berkaitan dengan hubungan principal dengan agent. Ketika hubungan kontraktual tersebut terjadi maka akan timbul biaya agensi (agency cost) (Anthony dan Govindarajan, 2007). Biaya agency didefinisikan sebagai biaya yang ditanggung oleh pemegang saham untuk mendorong manajer dalam memaksimalkan kesejahteraan pemegang saham daripada berperilaku mementingkan diri sendiri.

Apabila ukuran perusahaan berpengaruh positif itu berarti bahwa ternyata ukuran perusahaan dilihat dari besar atau kecilnya sebuah perusahaan,karena semua komponen pengawasan, pengendalian intern dan tata kelola di dalam perusahaan besar lebih bagus dibandingkan perusahaan kecil sehingga kinerja pada perusahaan besar semakin efektif dan efisien maka biaya semakin rendah, rendahnya biaya pengawasan dapat menciptakan kinerja yang baik bagi perusahaan perbankan sehingga mengakibatkan pengaruhnya menjadi positif.

Hasil Pengujian hipotesis menujukkan bahwa ukuran perusahaan berpengaruh positif pada kinerja keuangan perusahaan perbankan. Hal ini ditujukkan dengan nilai signifikan sebesar 0,005 yang nilainya lebih kecil dari tingkat signifikan yang ditetapkan $(\alpha=0,05)$ dan memiliki nilai koefisien sebesar 0,005 . Sehingga hipotesis kedua diterima yakni variabel ukuran perusahan terbukti berpengaruh positif pada kinerja keuangan. Hasil pengujian hipotesis tersebut mendukung hipotesis bahwa semakin besar ukuran perusahaan maka akan semakin tinggi pula kinerja keuangan perusahaan.

Ukuran perusahaan merupakan hal yang penting dalam proses pelaporan keuangan. Ukuran perusahaan dalam penelitian ini diukur dengan melihat seberapa besar asset yang dimiliki oleh sebuah perusahaan.Aset yang dimiliki 
perusahaan ini menggambarkan hak dan kewajiban serta permodalan perusahaan. Ukuran perusahaan akan berpengaruh pada perkembangan perusahaan. Hesti (2010) dan Uyun(2011) dalam penelitiannya menemukan bukti bahwa ukuran perusahaan berpengaruh positif pada kinerja keuangan perusahaan.Mahmood dan Abbas(2011) mengatakan bahwa ukuran perusahaan mempunyai hubungan positif pada kinerja keuangan perusahaan.Gill dan Obradovich (2017) mengatakan bahwa ukuran perusahaan mempunyai hubungan positif pada kinerja keuangan perusahaan. Perusahaan dengan aset besar biasanya akan mendapatkan perhatian lebih dari masyarakat. Hal ini akan menyebabkan perusahaan lebih berhati-hati dalam melakukan pelaporan keuangannya. Perusahaan diharapkan akan selalu berusaha menjaga stabilitas kinerja keuangan mereka.

\section{SIMPULAN}

Berdasarkan hasil analisis dan pembahasan maka dapat disimpulkan good corporate governance berpengaruh positifpada kinerja keuangan perusahaan perbankan tahun 2013-2017.Ukuran perusahaan berpengaruh positif pada kinerja keuangan perusahaan perbankan tahun 2013-2017. Hasil penelitian ini dapat memotivasi dan menginspirasi penelitian yang akan datang, untuk melakukan penelitian lebih lanjut yang berkaitan dengan kinerja keuangan perusahaan.

Berdasarkan simpulan, maka saran bagi peneliti adalah hasil nilai adjusted R Square sebesar 0,504 yang mengindikasikan bahwa terdapat 50,4 persen variabilitas kinerja auditor dijelaskan oleh variabel diluar model.Hal ini membuka peluang bagi peneliti selanjutnya untuk menambahkan variabel lain yang diduga berpengaruh pada kinerja keuangan perusahaan misalkan variabel struktur kepemilikan.Kepada perusahaan agar terus berupaya menerapkan seluruh komponen Good Corporate Governance sehingga dapat memperoleh peringkat CGPI yang terpercaya, dimana dengan peringkat yang diperoleh dapat menjadi pedoman bagi investor untuk dapat bergabung dalam menginvestasikan dananya.

\section{REFERENSI}

Anthony, R. N., \& Govindarajan, V. (2007). Management Control System - 12th Ed. Mcgraw-Hill International Edition.

Almadany, K. (2012). Pengaruh Loan To Deposit Ratio, Biaya Operasional Per Pendapatan Operasional Dan Net Interest Margin Terhadap Profitabilitas Perusahaan Perbankan Yang Terdaftar Di Bursa Efek Indonesia. Jurnal Riset Akuntansi $\mathcal{E}$ Bisnis, 12(2), 165-183. Retrieved from http://jurnal.umsu.ac.id/index.php/akuntan/article/view/171

Darmawati, D., Khomsiyah, \& Rahayu, R. G. (2005). Hubungan Corporate Governance Dan Kinerja Perusahaan. Jurnal Ilmu Riset Akuntansi Indonesia, 8(1), 1-12. Https:/ / Doi.Org/Http://Doi.Org/10.33312/Ijar.131

Epi, Y. (2017). Pengaruh Ukuran Perusahaan, Struktur Kepemilikan Manajerial Dan Manajemen Laba Terhadap Kinerja Perusahaan. Riset Dan Jurnal Akuntansi, 1(1), 1-7. Retrieved From Https://Media.Neliti.Com/Media/Publications/184099-ID-PengaruhUkuran-Perusahaan-Struktur-Kepe.Pdf 
Fallatah, Y., \& Dickins, D. (2012). Corporate Governance And Firm Performance And Value In Saudi Arabia. African Journal Of Business Management, 6(36), 10025-10034. Https://Doi.Org/10.5897/AJBM12.008

FCGI. (2001). Peranan Dewan Komisaris Dan Komite Audit Dalam Pelaksanaan Corporate Governance (Tata Kelola Perusahaan) (2nd Ed.). Jakarta: FCGI. Retrieved From Https://Muhariefeffendi.Files.Wordpress.Com/2009/12/Fcgi_Booklet_Ii. Pdf

Fidhayatin, S. K., \& Dewi, N. H. U. (2012). Analisis Nilai Perusahaan, Kinerja Perusahaan Dan Kesempatan Bertumbuh Perusahaan Terhadap Return Saham Pada Perusahaan Manufaktur Yang Listing Di BEI. The Indonesian Accounting Review, 2(2), 203-214. Https://Doi.Org/Http://Dx.Doi.Org/10.14414/Tiar.V2i02.96

Gill, A., \& Obradovich, J. (2017). The Impact Of Corporate Governance And Financial Leverage On The Value Of Amrican Firms. International Research Journal Of Finance And Economics, 12(4), 899-917. Https:/ / Doi.Org/10.12816/0034973

Hapsari, I. (2010). Hubungan Antara Good Corporate Governance Dan Transparansi Dengan Kinerja Perusahaan. Universitas Diponegoro Semarang.

Hesti, D. A. (2010). Analisis Pengaruh Ukuran Perusahaan, Kecukupan Modal,Kualitas Aktiva Produktif (Kap), Dan Likuiditas Terhadap Kinerja Keuangan. Universitas Diponegoro Semarang.

Huang, L.-Y., Carraher, S. M., \& Parnell, J. A. (2002). FDI Scale And Performance Of Taiwanese Family Firms In China: A Resource Based Perspective. Nova Southeastern University. Retrieved From Https:/ / Pdfs.Semanticscholar.Org/ A268/9094b282853179f73891e4b567173 2cdde7c.Pdf

Indarti, M. K., \& Extaliyus, L. (2013). Pengaruh Corporate Governance Preception Index (CGPI), Struktur Kepemilikan, Dan Ukuran Perusahaan Terhadap Kinerja Keuangan. Jurnal Bisnis Dan Ekonomi, 20(2), 171-183. Https:/ / Doi.Org/10.1017/CBO9781107415324.004

Isti'adah, U. (2015). Faktor-Faktor Yang Mempengaruhi Nilai Perusahaan Pada Perusahaan Manufaktu. Jurnal Nominal, 4(2), 57-72. Https:/ / Doi.Org/10.21831/Nominal.V4i2.8000

Isbanah, Y. (2013). Pengaruh ESOP, Leverage, Dan Ukuran Perusahaan Terhadap Kinerja Keuangan Perusahaan Di Bursa Efek Indonesia. Jurnal Research Economics And Management, 15(1), 2015. Retrieved From Http://Jrem.Iseisby.Or.Id/Index.Php/Id/Article/View/6/Pdf

Jensen, M. C. (1986). Agency Costs Of Free Cash Flow, Corporate Finance, And Takeovers Agency Costs Of Free Cash Flow, Corporate Finance, And Takeovers. The American Economic Review, 76(2), 323-329. Retrieved From Https://Www.Jstor.Org/Stable/1818789

Lin, K. L. (2006). Study On Related Party Transaction With Mainland China In Taiwan Enterprises. Guo Li Cheng Gong University China.

Mahmood, I., \& Abbas, Z. (2011). Impact Of Corporate Governance On Financial Performance Of Banks Inpakistan. Interdisciplinary Journal Of Contemporary 
Research In Business, 2(12), 217-228. Retrieved From Https://Www.Researchgate.Net/Publication/289539960

Memdani, L., Kandukuri, R. L., \& Raja, B. P. (2015). Effect Of Corporate Governance On Firm Performance? A Study Of Selected Indian Listed Companies. In Overlaps Of Private Sector With Public Sector Around The Globe (Vol. 31, Pp. 3-47). Emerald Group Publishing Limited. Https:/ / Doi.Org/Doi:10.1108/S0196-382120150000031010

Munawir. (2010). Analisis Laporan Keuangan (4th Ed.). Yogyakarta: Liberty.

Natalia, D., \& Laksono, E. P. (2013). Pengaruh Mekanisme Good Corporate Governance Terhadap Praktik Earning Managemeny Badan Usaha Sektor Perbankan di BEI 2008-2011. Jurnal Ilmiah Mahasiswa Universitas Surabaya, 2(1), 1-18. Retrieved from https://media.neliti.com/media/publications/189483-ID-none.pdf

Nuswandari, C. (2009). Pengaruh Corporate Governance Perception Index Terhadap Kinerja Perusahaan Pada Perusahaan Yang Terdaftar Di Bursa Efek Jakarta. Journal Bisnis Dan Ekonomi, 16(2), 70-84. Retrieved From Https:/ / Media.Neliti.Com/Media/Publications/24260-ID-PengaruhCorporate-Governance-Perception-Index-Terhadap-Kinerja-PerusahaanPada.Pdf

Paradita, D. (2009). Pengaruh Good Corporate Governance Terhadap Kinerja Keuangan Pada Perusahaan Yang Termasuk Sepuluh Besar Menurut Corporate Governance Perception Index (CGPI).Skripsi. Universitas Sumatera Utara.

Putri, W. (2006). Analisis Pengaruh Corporate Governance Dan Jumlah Komisaris Terhadap Kinerja Perusahaan.Skripsi. Universitas Islam Indonesia Yogyakarta.

Prasinta, D. (2012). Pengaruh Good Corporate Governance Terhadap Kinerja Keuangan. Accounting Analysis Journal, 1(2), 1-12. Https:/ / Doi.Org/10.15294/ Aaj.V1i2.655

Rachmawati, M. F. (2013). Analisis Pengaruh Pertumbuhan Dana Pihak Ketiga, Loan To Deposit Ratio, Non Performing Loan, Biaya Operasional Dan Net Interest Margin Terhadap Profitabilitas Bank (Studi Pada Bank Umum Yang Terdaftar Di Bursa Efek Indonesia Periode 2010-2012).Skripsi. Universitas Brawijaya Malang.

Sari, L. R. N. (2014). Pengaruh Ukuran Perusahaan, Leverage Dan Good Corporate Governance Terhadap Kualitas Laporan Keuangan Pada Perusahaan Manufaktur Yang Terdaftar Di BEI Tahun 2009-2012.Skripsi. Universitas Negeri Yogyakarta.

Scott, W. R. (2000). Financial Accounting Theory. USA: Prentice Hall.

Siahaan, I. D. (2008). Analisis Penerapan Good Corporate Governance Terhadap Kinerja Keuangan Perusahaan Yang Dikur Dengan Economic Value Added.Skripsi. Universitas Widyatama Bandung.

Sukartha, I. M. (2007). Pengaruh Manajemen Laba, Dan Kepemilikan Manajerial Pada Kesejahteraan Pemegang Saham Perusahaan Target Akuisisi. Jurnal Ilmiah Akuntansi Dan Bisnis Universitas Udayana, 1(3), 1-25. Retrieved From Https://Ojs.Unud.Ac.Id/Index.Php/Jiab/Article/View/2567/1782

Talebnia, G., Valipour, H., \& Shafiee, S. (2010). Empirical Study Of The 
Relationship Between Ownership Structure And Firm Performance: Some Evidence Of Listed Companies In Tehran Stock Exchange. Journal Of Sutainable Develeopment, 3(2), 264-270. Https://Doi.Org/10.5539/Jsd.V3n2p264

Uyun, S. (2011). Pengaruh Manajemen Risiko, Ukuran Perusahaan, Dan Leverageterhadap Kinerja Keuangan Perusahaan Pada Perusahaan Manufaktur Yangterdaftar Di Bursa Efek Indonesia.Skripsi. Universitas Airlangga Surabaya.

Wright, P., Kroll, M., Mukhreji, A., \& Pettus, M. L. (2009). Do The Contingencies Of External Monitoring,Ownership Incentives, Or Free Cash Flow Explain Opposing Firm Performance Expectations. Journal Management Governance, 13(1), 215-243. Https:/ / Doi.Org/10.1007/S10997-008-9063-8. 